\title{
Genetic Improvement of Temperate Grasses and Legumes in Indian Himalayan Region: A Review
}

\author{
V. K. Sood, H. K. Chaudhary, Anjali Kumari*, Hausila Prasad Singh, \\ Rajni Devi and Ankita Sharma
}
Department of Crop Improvement, CSK Himachal Pradesh Agricultural University, Palampur-176062, India

*Corresponding author

\begin{abstract}
A B S T R A C T
Pastures in Indian Himalayas are based largely on annual and perennial temperate species that are rich in biodiversity but have less productivity. The main temperate grass and

\section{Keywords}

Backcross hybrids; dry matter digestibility; palatability; red clover; winter hardiness and white clover etc.

Article Info

Accepted: 26 May 2018 Available Online: 10 June 2018 legume species prevalent are perennial ryegrass, tall fescue, festulolium hybrid, red and white clovers. Fescue grass consists of two agriculturally important forage crops, hexaploid tall fescue and diploid meadow fescue. Ryegrass contains two widely cultivated temperate species, Italian or annual ryegrass and perennial ryegrass. Both species are naturally diploid and are closely related to fescues. Festulolium hybrids have been developed by crossing fescue to ryegrass to combine the desirable traits of both species and broaden the genetic pool. Red clover contains an enzyme polyphenol oxidase (PPO) which reduces the losses of protein. Thus the genotypes/ lines containing high PPO are rich in protein and can be further used in the breeding programme. Breeding of white and red clover builds on the advantages of these species in terms of their impact on animal performance, fatty acid profiles and flavour. Further improvement in germplasm of temperate forage grasses can be made by linking of physiology and genomics, integration of genomics with classical breeding combined with appropriate phenotypic analysis of key traits will be essential for the development of improved forage cultivation.
\end{abstract}

\section{Introduction}

Middle hills occupy $35 \%$ of total grassland vegetation of Indian Himalayan region. This grassland vegetation includes cold temperate grasses, subalpine and alpine meadows of the great Himalayas (Rawat, 1998). Temperate areas are primarily situated between 2000$4500 \mathrm{~m}$ amsl with significant biodiversity. In India, Jammu \& Kashmir, Himachal Pradesh, Uttarakhand, Sikkim and Arunachal Pradesh are the states where temperate/alpine pastures are abundant. Pastures in Indian Himalayas are based largely on annual and perennial temperate species that are rich in biodiversity but have less productivity. Forage crops are the major source of livestock economy but are vulnerable to some of the major constraints like overgrazing, anti-nutritional factors, drought and frost susceptibility. One of the main impediments in the improvement of livestock is the unavailability of qualitative and quantitative fodder which could only be overcome by growing high yielding fodder 
crops like fescue, ryegrass etc. to increase fodder production per unit area. These crops provide fodder not only for few months but round the year. Some of the fodder crops like fescues are tolerant to drought as well as cold. These desirable features can be introgressed to other related crops like ryegrass to enhance the efficiency and persistency of both the crops. Legume fodder like red clover contains a high amount of desirable proteins, but along with that they also contain some antinutritional factors causing harmful effect on fodder quality. White clover contains $\mathrm{HCN}$ that causes blotting in animals which is injurious to animal health. Since forages are the major source of livestock feed and contribute towards the increasing amount of milk and meat production, hence breeding efforts should be made to improve the potential of forage crops.

\section{Major threats to temperate grasses and legumes}

\section{Overgrazing by livestock}

When the land is exposed to intensive grazing for a prolonged period of time, there is complete damage to the vegetation and overgrazing occurs. Plants do not have enough time to recover to the proper height and restored carbohydrate reserves which results in erosion and degradation of the land.

\section{Obnoxious weed}

It is defined as a harmful or injurious weed that causes devastating loss to agriculture or livestock and is harmful to human health. They are poisonous to both humans as well as animals.

\section{Low persistence}

Despite being perennial species, they start behaving as annuals or biennials and this reduces their productive potential in the long run.

\section{Low Productivity}

Since temperature is low in the temperate climate, it affects overall yield of fodder grass. During the winter season growth of temperate grass is extremely affected by chilling temperature. The amount of photosynthesis is also reduced by the low availability of light.

The advantages of temperate grasses over sub-tropical grasses

Temperate grasses have higher nutritive value i.e. higher dry matter digestibility, due to lower lignin content.

The optimum temperature for growth of temperate grasses is about $20^{\circ} \mathrm{C}$ while for subtropical grasses it is much higher $\left(25-35^{\circ} \mathrm{C}\right)$. Consequently, temperate grasses grow actively in winter when sub-tropical grasses are dormant.

There is a cold zone where the persistence of most sub-tropical grasses is adversely affected by the combination of cold, wet soils and frosts. The temperate perennial grasses are persistent and highly productive in this area. As a result, there is a large potential for temperate perennial grasses to be grown widely in the medium to high rainfall areas of this cold zone, which is largely used for growing pastures with only a small proportion under crop.

\section{Major temperate grasses and legumes are grown in Himalayan regions}

\section{Fescue}

The genus Festuca is one of the largest in Gramineae. It comprises of some 450 species (Clayton and Renvoize, 1986) that range from 
diploid $(2 \mathrm{n}=2 \mathrm{x}=14)$ to dodecaploid $(2 \mathrm{n}=$ $12 \mathrm{x}=84$ ) in chromosome number (Smarda and Stanc1k, 2006). The genus Festuca contains two agriculturally important forage crops, hexaploid tall fescue $F$. arundinacea $(2 \mathrm{n}=6 \mathrm{x}=42)$ and diploid meadow fescue $F$. pratensis $(2 \mathrm{n}=2 \mathrm{x}=14)$. Other fescues of some importance are red fescue, $F$. rubra $(2 \mathrm{n}=6 \mathrm{x}=42$ or $8 \mathrm{x}=56)$, and sheep fescue, $F$. ovina $(2 \mathrm{n}=4 \mathrm{x}=28)$. The agriculturally undeveloped species, giant fescue $F$. gigantea is important because it produces a mass of very large soft leaves of high nutritive value. Tall fescue is the most important forage species worldwide of the Festuca genus. It is indigenous to Europe and also occurs naturally on the Baltic coasts throughout the Caucasus in western Siberia and extending into China (Jauhar, 1993). It is a long-lived perennial, cool season, high yielding and drought tolerant bunch grass. It is valued for its betterstockpiling properties, tolerate hot dry conditions, frost conditions, pasture pest attack and to produce leafy green herbage over the summer. Typically this species of grass has a long growing season and ranges between 2 to 4 feet tall in seed head stage. It spreads through rhizomes. New emerging leaves are rolled in the bud with no prominent ligules which make this a key identification feature of tall fescue. The upper leaf surface is dull with distinct veins running on it, whereas the upper surface is smooth with rough edges.

\section{Genetics}

Majority of tall fescue cultivars are allohexaploid with 42 chromosomes. The genomic constitution of hexaploid tall fescue consists of two groups of chromosomes originated from Meadow fescue (Lolium pratensis) designated PP and tetraploid fescue (Festuca arundinacea var. glaucescens), designated $\mathrm{G}_{1} \mathrm{G}_{1} \mathrm{G}_{2} \mathrm{G}_{2}$. Tall fescue has a large genome i.e. $5.27-5.83 \times 10^{6} \mathrm{~kb}$. It is predominantly cross-pollinated species with a high level of self-incompatibility. It is highly heterozygous and heterogeneous.

\section{Traits of Interest in Tall Fescue Breeding}

\section{Drought tolerance}

Most of the tall fescue species are tolerant to drought but, this trait is correlated with traits. Johnson and Yangyang (1999) were successful in selecting for decreased $\mathrm{C}^{13}$ isotope discrimination which has been associated with increased water use efficiency but gives low forage yield.

\section{Digestibility}

Primary limit to animal performance in tall fescue is endophyte toxicity. Endophyte is a fungus (Neotyphodium coenophialum) that lives inside the tall fescue plant in a symbiotic relationship. Host plant becomes resistance to insect attack, drought and moisture stress. Animals feeding on fescue grass infected with endophyte suffer from fescue toxicity and fescue foot. This reduces the ability of animals to cool themselves and also causes lameness and weight loss. Some of the earlier varieties of tall fescue (Alta, Kentucky-31) contained endophyte. New strains of endophytes have been identified that contain less or no amount of toxic alkaloids. Nontoxic endophyte cultivars can improve animal weight gains by as much as 60-100\% (Bouton et al., 2002; Hopkins and Alison, 2006). Endophyte-free cultivars are Alta, Kenhy, and KY-31. Increased digestibility is expected to enhance these gains further and will remain an important breeding objective to develop early maturity varieties.

\section{Increased palatability}

Palatability of tall fescue declines as it is allowed to over-mature. Cultivars such as Lubrette, Adora, Quantum, and Advance were 
selected for leaf softness in an effort to improve intake and palatability. Increasing palatability of tall fescue when it grows tall is another important aspect.

\section{Quality traits}

Under grazing conditions, crude protein and dry matter digestibility (DMD) start increasing in spring as well as with the onset of the autumn season whereas start decreasing in summer.

In the mid-hill Himalayan conditions the dry matter, NDF, ADF and hemicellulose content increased while crude protein, IVDMD, leaf stem ratio and oxalate decreased with an increase in the age of plants.

Tall fescue grass retains maximum nutritive value during the month of March and April (Katoch et al., 2012).

\section{Ryegrass}

The genus Lolium contains two widely cultivated temperate species, Lolium multiflorum (Italian or annual ryegrass) and $L$. perenne (perennial ryegrass). They are characterized by a bunch of growth habits.

It is native to Europe, Asia, and northern Africa. It is naturally diploid $(2 n=14)$ and is closely related to fescues. It should not be confused with rye (Secale cereale), which is a grain crop.

\section{Lolium multiflorum}

It is commonly known as Australian ryegrass, short rotation ryegrass and westerwolds ryegrass. It differs from $L$. perenne in its spikelet which has a long bristle at the top and its stem is round rather than folded. It is mainly grown as silage or an ornamental grass.

\section{Lolium perenne}

It is commonly known as English grass or winter grass, tufted and hairless with a bunching type of growth habit. The leaves are dark green in colour on the lower surface having a smooth and glossy texture with prominent parallel veins on the upper surface.

\section{Genetics}

Comparisons of the relative positions of RFLP probes CDO545, RZ144, R2869 and C764 in $L$. perenne and rice indicated a region of synteny between $L$. perenne $\mathrm{L} 7$ and rice chromosome 6 which covered the region of the rice genome containing the $\mathrm{Hd} 3$ locus (Yamamoto et al., 1998). Additionally, QTLs for heading date have also been identified on chromosome 7 of wheat and barley (Laurie et al., 1995; Worland et al., 1998; Borner et al., 2002) to which Lolium is more closely related than to rice.

\section{Traits of Interest in Ryegrass Breeding}

\section{Disease resistance}

The occurrence and severity of rust diseases caused by Puccinia graminis and $P$. coronata are decreased in perennial ryegrass cultivated for forage if grown in mixture with other grass species (Roscher et al., 2007).

Resistance to crown rust in perennial ryegrass appears to be controlled by both major and minor genes (Kimberg, 1999).

\section{Herbicide tolerance}

The economic value of perennial rye grass seed diminishes when it is mixed with the seed of Quack grass which acts as a weed. Perennial ryegrass is tolerant to Assure II (Herbicide) but this herbicide effectively controls quack grass. 


\section{Winter Hardiness}

Initially, NK 200 was the key source for winter hardiness but it was poor in quality and susceptible to crown rust. This trait of winter hardiness was transferred from NK 200 to perennial ryegrass.

\section{Lodging resistance}

Seventeen QTLs related to lodging resistance have been detected for six traits in Italian ryegrass. Out of these QTLs, qHD6, qHD7, qCPR6, qCPR1 and qCPR5-1 had high lod score.

\section{Festulolium hybrid}

Festulolium is an intergeneric hybrid between Festuca and Lolium species. This hybridization provides plant breeder with greater opportunity to introgress the important traits from Festuca to Lolium and vice versa.

The hybrids generated from the cross between diploid species have low fertility which can be restored by giving colchicine treatment followed by doubling the chromosome numbers.

Partially male and female fertile $F_{1}$ hybrids can also be obtained by crossing autotetraploid of Lolium sp. and F. pratensis.

The first amphidiploid Festulolium cultivars Elmet (L. multiflorum $\times F$. pratensis) and Prior $(L$. perenne $\times F$. pratensis) were bred at the Welsh Plant Breeding Station, in the early 1970s (Thomas and Humphreys, 1991).

\section{Introgression in Lolium/Festuca}

Ryegrasses have excellent productivity and more digestible to the ruminant animal. However, several of the fescues, though lacking some of the qualities of ryegrass, are superior in other respects. It has long been our wish to combine the complementary characteristics of ryegrass and fescue. Humphreys et al., (2005) hybridized Festuca arundinacea var. glaucescens accession $\mathrm{Bn}$ $354-4(2 n=4 x=28)$ with Bb 2264-2, a genotype from a synthetic autotetraploid Lolium cultivar to transfer the drought resistance from Festuca into Lolium and the results were analyzed by cytological studies.

\section{Trifolium}

The clover genus Trifolium has 250-300 species (Zohary and Heller, 1984; Ellison et al., 2006) about $10 \%$ of which are used as forage plants in commercial agriculture. Clovers, like most legumes, are co-evolved complexes of the plant, symbiotic bacteria (Rhizobium leguminosarum var. trifolii), fungi and insect pollinators.

\section{White clover}

White clover (Trifolium repens) commonly known as Dutch clover or Ladino clover is the most common cultivated clover species worldwide (Ellison et al., 2006).

It belongs to the family Fabaceae and native to Europe, Middle East, and North Africa. It is a herbaceous, perennial, low growing plant with heads of whitish flowers often with a tinge of pink or cream that may come on with the ageing of the plant. The leaves are trifoliate, smooth and elliptic to egg-shaped with long petiole.

It often forms a mat with the stems creeping as much as $18 \mathrm{~cm}$ in a year and rooting at the nodes. The leaves form the symbol known as shamrocks. It improves the nutritional value of pasture by increasing its protein and mineral content (Reid and Strachan, 1974) and also improves its digestibility and palatability (Jones and Roberts, 1991). 
Table.1 DNA contents and breeding system in Lolium species

\begin{tabular}{|c|c|c|c|c|}
\hline S. No. & Species & Mode of breeding & Habit & DNA content (pg) \\
\hline 1 & L. perenne & Outbreeder & Perennial & 4.15 (Evans et al., 1972) \\
\hline 2 & L. multiflorum & Outbreeder & Biennial & 4.31(Rees and Jones, 1967) \\
\hline 3 & L. rigidum & Outbreeder & Annual & 4.33 (Hutchinson et al., 1979) \\
\hline 4 & L. canariense & Outbreeder & Annual & 4.23 (Hutchinson et al., 1979) \\
\hline 5 & L. temulentum & Inbreeder & Annual & 6.23 (Hutchinson et al., 1979) \\
\hline 6 & L. remotum & Inbreeder & Annual & 6.04 (Hutchinson et al., 1979) \\
\hline 7 & L. persicum & Inbreeder & Annual & 6.35 (Hutchinson et al., 1979) \\
\hline 8 & L. subulatum & Inbreeder & Annual & 5.49 (Hutchinson et al., 1979) \\
\hline
\end{tabular}

Table.2 Chromosome numbers and DNA contents of some Festuca and Lolium species (Kopecky et al., 2008)

\begin{tabular}{|l|}
\hline Species \\
\hline Festuca arundinacea \\
\hline F. arundinacea var. glaucescens \\
\hline Festuca gigantea \\
\hline Festuca mairei \\
\hline Festuca pratensis \\
\hline Festuca scariosa \\
\hline Lolium perenne \\
\hline Lolium multiflorum \\
\hline
\end{tabular}

\begin{tabular}{|c|c|c|}
\hline Common name & $\begin{array}{l}\text { Chromosome } \\
\text { number }\end{array}$ & DNA content (pg) \\
\hline Tall fescue & $2 n=6 x=42$ & 6.05 \\
\hline- & $2 n=4 x=28$ & 4.28 \\
\hline Giant fescue & $2 n=8 x=56$ & 7.23 \\
\hline Atlas fescue & $2 n=4 x=28$ & 3.95 \\
\hline Meadow fescue & $2 n=2 x=14$ & 2.20 \\
\hline- & $2 n=2 x=14$ & 2.68 \\
\hline Perennial ryegrass & $2 n=2 x=14$ & 2.08 \\
\hline Italian ryegrass & $2 n=2 x=14$ & 4.10 \\
\hline
\end{tabular}

Table.3 Festulolium cultivars developed in Europe and USA (Yamada et al., 2005)

\begin{tabular}{|c|c|c|c|c|}
\hline Type & Hybrid combination & $\begin{array}{l}\text { Cultivar } \\
\text { name }\end{array}$ & Country & Year \\
\hline \multirow[t]{7}{*}{ Amphidiploid } & \multirow{2}{*}{ L. multiflorum $\times F$. pratensis } & Perun & Czech Republic & 1991 \\
\hline & & Rakopan & Poland & 2001 \\
\hline & \multirow[t]{3}{*}{$F$. pratensis $\times$ L. multiflorum } & Paulena & Germany & 1995 \\
\hline & & Punia & Lithuania & 1997 \\
\hline & & Agula & Poland & 2002 \\
\hline & \multirow[t]{2}{*}{ L. perenne $\times F$. pratensis } & Prior & U.K. & 1973 \\
\hline & & Spring Green & USA & 2001 \\
\hline \multirow[t]{2}{*}{ Introgression } & \multirow{2}{*}{$\begin{array}{c}\text { L. } \text { multiflorum } \times F \text {. } \\
\text { arundinacea }\end{array}$} & Kenhy & USA & 1977 \\
\hline & & Johnston & USA & 1983 \\
\hline
\end{tabular}

Genetics

Most of the White clover cultivars are naturally tetraploid $(2 n=4 x=32)$ species with disomic (amphidiploid) inheritance (Williams et al., 1998). The diploid ancestors of white clover are T. pallescens and T. occidentale. 
The genome size of white clover has been reported as $0.559 \mathrm{pg}$ (Vizintin et al., 2006).

\section{Traits of interest in white clover breeding}

\section{Pest and Disease Tolerance}

White clover is susceptible to many pests and diseases however, the wild relatives of white clover are resistance to most of the diseases i.e. $T$. uniflorum $(2 \mathrm{n}=32)$ is resistance to grass grub (Costelytra zealandica) due to nutritional quality of the roots, absence of feeding stimulants or the production of feeding deterrents (Dymock et al., 1989), T. nigrescens and $T$. ambiguum is resistant to southern root-knot nematode (Meloidogyne incognita) (Pederson and Windham, 1989). So, the resistance of $T$. uniflorum, $T$. nigrescens and T. ambiguum could be utilized in $T$. repens by hybridization. Till now, an interspecific hybrid between T. uniflorum $\times$ $T$. repens has some problems. No seed formation takes place from both $T$. uniflorum $\times T$. repens and $T$. repens $\times T$. uniflorum crosses, but there is observed development of embryos after hybridization of compatible genotypes (Evans, 1962). With the use of embryo rescue, successful production of seedlings from each cross takes place.

\section{Introgression of drought tolerance trait from Caucasian clover}

It is more drought tolerant than white clover which may be conferred by its rhizomes. Marshall et al., (2001) developed Backcross hybrids between white clover and Caucasian clover, using white clover as the recurrent parent and found that when drought stress is induced, white clover was the least able to withstand drought than Backcross hybrids.

\section{Genetic diversity in white clover}

The genetic diversity of 28 white clover accessions was studied by Sharma et al.,
(2005) and grouped into seven clusters showing a high level of genetic divergence. Molecular variation of the higher order was resolved in the exotic accessions to compare to the indigenous germplasm. This suggests the need to introduce this germplasm in the Indian white clover gene pool to increase the genetic diversity.

\section{Molecular markers}

In collaboration with Plant Biotechnology Centre, Victoria, Australia, IGER have developed the first molecular genetics map of white clover and have delineated the genetic control of important agronomic traits. Additionally, fatty acid profiling of the individual genotypes is underway to identify genetic loci underpinning variation in individual fatty acids.

\section{Red clover}

It is a high yielding forage legume with high nutritional value and protein content. It helps in fixing atmospheric nitrogen and is native to Europe, Western Asia, and northwest Africa but planted and naturalized in many other regions also. It belongs to the family Fabaceae. It is a herbaceous, short-lived perennial plant with variable size and 20-80 $\mathrm{cm}$ tall.

\section{Genetics}

Red clover is a diploid species with the diploid chromosome number 14. It is heterozygous due to its gametophytic selfincompatibility system.

\section{Advantages of Red Clover}

Long productive season. It will continue to grow throughout the summer whenever moisture is available. It can tolerate heat and drought much better than white clover. 
Seedling vigour of red clover is excellent and much better than any other clover or alfalfa, making it easy to get good stands.

It has high forage yield potential.

It is adapted to a wide range of soils.

\section{Traits of interest in Red clover breeding}

\section{Enhanced grazing tolerance}

Current varieties lack the ability to withstand overgrazing by the cattle. Enhanced grazing tolerance of these varieties will allow the farmers to have more productivity of red clover and fewer chances of crop failure.

\section{Pest and disease resistance}

Eelworm/stem nematode is a major pest of red clover that causes swollen and distorted stems and/or flower with short and stunted plants. A major disease of red clover is clover rot caused by Sclerotinia sp., both of these causes huge loss of biomass production in red clover.

\section{Quality traits}

\section{Low level of phyto-oestrogen}

Red clover varieties have reduced levels of the major phyto-oestrogen. These compounds can reduce fertility, particularly in ewes and a variety with lower level would increase the versatility of the crop. The variety Aber Ruby has low levels of the phyto-oestrogens that at higher levels cause reduced fertility in ewes.

\section{Polyphenol oxidase}

Following cellular damage, PPO catalyzes the conversion of phenols to quinones that bind to proteins, protecting them from early degradation and preventing subsequent formation of polluting ammonia. The action of this enzyme is to reduce the losses of protein during silage making. This results in increased protein utilization by ruminant animals.

\section{Polyunsaturated fatty acids}

It is another beneficial feature of red clover. There is clear evidence that meat and milk from animals fed on diets high in red clover (typically silage) contains more of those Polyunsaturated fatty acids which is beneficial for human health.

Selection for increased levels of these compounds in leaves will provide germplasm that will be used to test the effectiveness of this approach in raising levels in animal products.

\section{Analyzing gene expression changes underpinning key traits}

Gene expression studies are in progress involving a network of collaborations and a range of approaches to identify the key genes involved in nodule and root senescence. The effects of root and nodule death on legume persistency, soil structure, composition and leaching are not well understood but are likely to have a significant impact on agroecosystems. Individual nodules show visible signs of early senescence but recover from this temporary stress with no apparent loss of function.

\section{Future Prospectus}

A key consideration for the future will be the harnessing of the power of genomics, linking of physiology and genomics.

Integration of genomics with classical breeding combined with appropriate phenotypic analysis of key traits will be 
essential for the development of improved forage cultivation.

\section{References}

Borner, A., Schumann, E., Furste, A., Coster, H., Leithold, B., Roder, M.S. and Weber, W.E. 2002. Mapping of quantitative trait loci determining agronomic important characters in hexaploid wheat (Triticum aestivum L.). Theor. Appl. Genet., 105: 921-936.

Bouton, J.H., Latch, G.C.M., Hill, N.S., Hoveland, C.S., McCann, M.A., Watson, R.H., Parish, J.A., Hawkins, L.L. and Thompson, F.N. 2002. Reinfection of tall fescue cultivars with non-ergot alkaloidproducing endophytes. Agron. J., 94: 56754.

Clayton, W.D. and Renvoize, S.A. 1986. Genera Graminum. Grasses of the world. Kew Bull Add Ser 13: 1-389.

Dymock, J.J., Van den Bosch, J., Caradus, J.R. and Lane, G.A. 1989. Growth and survival of grass grub, Costelytra zealandica, (white) (Coleoptera: Scarabaedae) on Trifolium species and $T$. repens and $T$. uniflorum hybrids. N. Z. J. Agric. Res., 32: 389-394.

Ellison, N.W., Liston, A., Steiner, J.J., Williams, W.M. and Taylor, N.L. 2006. Molecular phylogenetics of the clover genus (Trifolium - Leguminosae). Mol. Phylogenet. Evol., 39: 688-705.

Evans, A.M. 1962. Species hybridization in Trifolium. I. Methods of overcoming species incompatibility. Euphytica, 11: 164-176.

Evans, G.M., Rees, H., Snell, C.L. and Sun, S. 1972. The relationship between nuclear DNA amount and the duration of the mitotic cycle. Chromosomes Today, 3: 2431.

Hopkins, A.A. and Alison, M.W. 2005. Stand persistence and annual performance of tall fecue endophyte combinations in the south central USA. Agron. J., 98: 1221-1226.
Humphreys, J., Harper, J.A., Armstead, I.P. and Humphreys, M.W. 2005. Introgressionmapping of genes for drought resistance transferred from Festuca arundinacea var. glaucescens into Lolium multiflorum. Theor. Appl. Genet., 110: 579-587.

Hutchinson, J., Rees, H. and Seal, A.G. 1979. Assay of the activity of supplementary DNA in Lolium. Heredity, 43: 411-421.

Jauhar, P.P. 1993. Cytogenetics of the FestucaLolium complex. Springer, Heidelberg.

Johnson, R.C. and Yangyang, L. 1999. Water relations, forage production and photosynthesis in tall fescue divergently selected for carbon isotope discrimination. Crop Sci., 39: 1663-1670.

Jones, K.L. and Roberts, J.E. 1991. A note on the relationship between palatability and water soluble carbohydrate $\mathrm{s}$ content in perennial ryegrass. Ir. J. Agric. Res., 30: 163-167.

Katoch, R.S., Thakur, M. ad Kumar, N. 2012. Effect of morphological stage and clipping intervals on quality and digestibility of tall fescue (Festuca arundinacea Schreb.) and Setaria (Setaria anceps Stapf.). Range Manag. Agrofor. 33: 185-192.

Kimberg, C.A. 1999. Genetic basis of crown rust resistance in perennial ryegrass, breeding strategies and genetic variation among pathogen population: a review. Aust. J. Exp. Agri., 39: 361-378.

Kopecky, D., Lukaszewski, A.J. and Dolezel, J. 2008. Cytogenetics of Festulolium (Festuca/Lolium hybrids). Cytogenet. Genome Res., 120: 370-383.

Laurie, D.A., Pratchett, N., Bezant, J.H. and Snape, J.W. 1995. RFLP mapping of five major genes and eight quantitative trait loci controlling flowering time in winter spring barley (Hordeum vulgare L.) cross. Genome, 38: 575-585.

Marshall, A.H., Rascle, C., Abberton, M.T., Yeates, T.P.T. and Rhodes, I. 2001 Introgression as a Route to Improved Drought Tolerance in White Clover (Trifolium repens L.) J. Agron. Crop Sci., 187: 11-18. 
Pederson, G.A. and Windham, G.L. 1989. Resistance to Meloidogyne incognita in Trifolium interspecific hybrids and species related to white clover. Plant Dis., 73: 567569.

Rawat, G.S. 1998. Temperate and alpine grasslands of the Himalaya: ecology and conservation. Parks, 8: 27-36.

Rees, H. and Jones, G.H. 1967. Chromosome evolution in Lolium. Heredity, 22: 1-18.

Reid, R.L. and Strachan, N.H. 1974. The effects of a wide range of nitrogen rates on some chemical constituents of the herbage from perennial ryegrass swards with and without white clover. J. Agric. Sci., 83: 393-401.

Roscher, C., Schumacher, J., Foitzik, O. and Schulze, E.D. 2007. Resistance to rust fungi in Lolium perenne depends on within species variation and performance of the host speies in grasslands of different plant diversity. Oecologia, 153: 173-183.

Sharma, A. 2013. Genetic characterization of elite genotypes of tall fescue grass (Festuca arundinacea) Ph.D Thesis $\mathrm{p}$ 70-85. Department of Crop Improvement, CSK Himachal Pradesh Krishi Vishvavidyalaya, Palampur, India.

Sharma, T.R., Singh, S., Rathour, R. and Sharma, S.K. 2005. Analysis of genetic diversity in white clover (Trifolium repens) breeding populations using agromorphological and RAPD markers. $X X$ international grassland congress.

Smarda, P. and Stancik, D. 2006. Ploidy level variability in South American fescues (Festuca L., Poaceae): use of flow cytometry in up to $51 / 2$ year old caryopses and herbarium specimens. Plant Biol., 8: 73-80.

Thomas, H. and Humphreys, M.O. 1991. Progress and potential of interspecifi hybrids of Lolium and Fetuca. J. Agric. Sci., 117: 1-8.

Vizintin, L., Javornik, B. and Bohanec, B. 2006. Genetic characterization of selected Trifolium species as revealed by nuclear DNA content and ITS rDNA region analysis. Plant Sci., 170: 859-866.

Williams, W.M., Mason, K.M. and Williamson, M.L. 1998. Genetic analysis of shikimate dehydrogenase allozymes in Trifolium repens L. Theor. Appl. Genet., 96: 859868.

Worland, A.J., Burner, A., Korzun, V., Li, W.M., Petrovic, S. and Sayers, E.J. 1998. The influence of photoperiod genes to the adaptability of European winter wheats. Euphytica, 100: 385-394.

Yamada, T., Forster, J.W., Humphreys, M.W. and Takamizo, T. 2005. Genetics and molecular reeding in Lolium/Festuca grass species complex. Grassl. Sci., 51: 89-106.

Yamamoto, T., Kuboki, Y., Lin, S.Y., Sasaki, T. and Yano, M. 1998. Fine mapping of quantitative trait loci $\mathrm{Hd}-1$, Hd-2 and Hd-3, controlling heading date of rice, as single Mendelian factors. Theor. Appl. Genet., 97: 37-44.

Zohary, M. and Heller, D. 1984. The genus Trifolium. Israel Academy of Sciences and Humanities, Jerusalem, Israel.

\section{How to cite this article:}

Sood, V. K., H. K. Chaudhary, Anjali Kumari, Hausila Prasad Singh, Rajni Devi and Ankita Sharma. 2018. Genetic Improvement of Temperate Grasses and Legumes in Indian Himalayan Region: A Review. Int.J.Curr.Microbiol.App.Sci. 7(06): 3454-3463. doi: https://doi.org/10.20546/ijcmas.2018.706.405 